\title{
ERJ
}

Engineering Research Journal

Faculty of Engineering

Menoufia University

\section{DUCTILITY OF STRENGTHENED R.C BEAMS WITH LAP SPLICES}

\author{
G. I. khaleel 1, A. S. Debaiky 2, M. H. Mansour 3, Marwa I. Badawi 4* \\ ${ }^{I}$ Prof. of Reinforced Concrete, Civil Engineering Department, Faculty of Engineering, Benha \\ University, Cairo, Egyp. \\ ${ }^{2}$ Associate Prof, Civil Engineering Department, Faculty of Engineering, Benha University, \\ Cairo, Egypt. \\ ${ }^{3}$ Lecturer, Civil Engineering Department, Faculty of Engineering, Benha University, Cairo, \\ Egypt. \\ ${ }^{4}$ Demonstrators, Civil Engineering Department, Faculty of Engineering, Benha University, \\ Cairo, Egypt.
}

\begin{abstract}
Studying the ductility of strengthened reinforced concrete beams with varying lap splices is very important for the development of the structural behavior of RC beams. When reinforcement is spliced together within a concrete beam, it is necessary to overlap the bars long enough to transfer the tensile stresses between spliced bars without inducing a pullout failure in the concrete. Most design codes allow the use of bars with lap splice and specify minimum length of the lap as well as the required transverse reinforcement. The objective of this research is to study the behavior of reinforced concrete simply-supported beams with lap splice at tension reinforcement. The tension reinforcement of these beams will be spliced at different locations, with different numbers of lap spliced bars and by using different percentages of reinforcement. Transversal FRP strips will be used to strengthen the RC beams with different lap splice types in order to improve their ductilities. Each of glass and carbon fiber will be used to fabricate the FRP strips. This study concludes that FRP wrapping provided greater ease of application, make beams more ductility.

\section{Arabic Abstract}

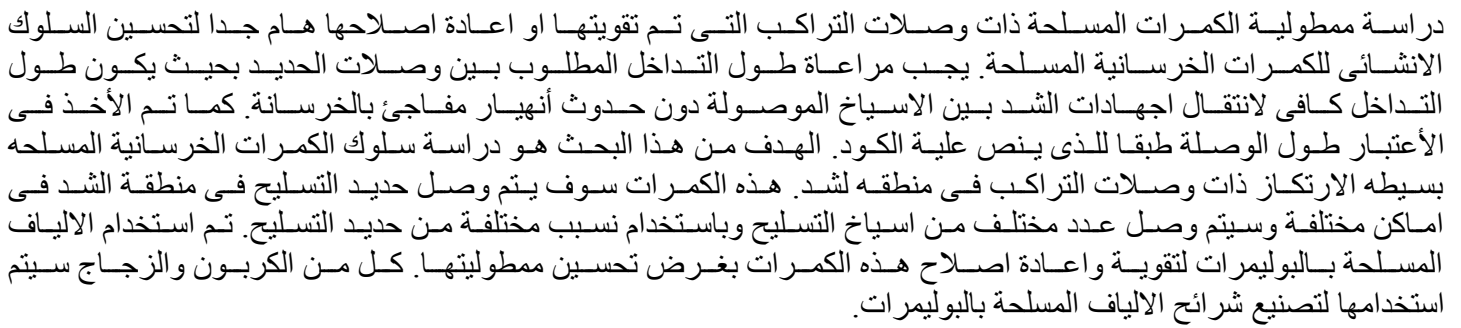

Keywords: ductility; FRP; lap splices; tensile stresses; transverse reinforcement; tension reinforcement; strengthen.

\section{INTRODUCTION}

Studying the ductility of strengthened reinforced concrete beams with lap splices is very important for the development of the structural behavior of RC beams. When reinforcement bars are spliced together within a concrete beam, it is necessary to overlap the bars long enough to transfer the tensile stresses between spliced bars without inducing a pullout failure in the concrete. Most design codes allow the use of bars with lap splice. They specify the minimum length of the overlap as well as the required transverse reinforcement. Ductility may be defined as the ability to under-go deformation without a substantial reduction in the capacity of the member. The curvature ductility factor is a fair more meaningful index for ductility demand, that is because, once plastic hinge has commenced in the structure, the deformation concentrated at the plastic hinge position is caused by the rotation of the plastic hinge. The fundamental information needed by the designer concerns the required member section behavior at the plastic hinge expressed by the curvature ductility factor and its variation with the type of steel used and ratio of compression reinforcement [1].

Fiber reinforced polymer (FRP) materials have been increasingly used in the last two decades to improve various structural characteristics of reinforced concrete

Engineering Research Journal, Vol. 39, No. 4, October 2016, PP: 285-300 
(RC) bridges, buildings and other structures. Ductility of the resulting FRP-concrete system plays an important role in structural performance, especially in certain applications such as earthquake resistant structures, where ductility and energy dissipation play a vital role [2].

Fiber reinforced polymer (FRB) reinforcement has been used over the last few years in the form of laminates, sheets and strips for repair of concrete structures. The non-corrosive characteristics and good fatigue properties of CFRP, significantly, increase the service life of structure. The high strength and low weight of FRB makes it feasible compared to conventional materials used in repair [3].

This research studies the behavior of simply-supported reinforced concrete beams with lap splices at the tension reinforcement. The tension reinforcement of these beams will be spliced at different locations, with different number of lap spliced bars and by using different percentages of reinforcement. Transversal FRP strips will be used to strengthen the RC beams in order to improve their ductility. Both of glass and carbon fiber will be used for the FRP strips.

\section{EXPERIMENAL PROGRAM 2.1 TESTED SPECIMENS}

In this paper test specimens were fabricated to investigate ductility of strengthened RC beams with lap splices with CFRP and GFRP wrapping. The results obtained from an experimental investigation on 18 reinforced concrete beams. The test program includes: Casting of beams (120 x 250 × $3200 \mathrm{~mm})$, strengthening beams specimens by wrapping with CFRP and GFRP strips. Table.1.shows the eighteen simply supported reinforced concrete beams of the test program.

The program included sixteen beams, the internal longitudinal tensile steel reinforcement consisted of four $12 \mathrm{~mm}$ diameter bars at the bottom $\left(\mathrm{fy}=360 \mathrm{~N} / \mathrm{mm}^{2}\right.$ ), two $10 \mathrm{~mm}$ diameter bars at the top of the beam (fy = $245 \mathrm{~N} / \mathrm{mm}^{2}$ ), and 8-mm diameter stirrups at $200 \mathrm{~mm}$ $\left(\right.$ fy $=245 \mathrm{~N} / \mathrm{mm}^{2}$ ). One beam consisted of three $12 \mathrm{~mm}$ diameter bars at the bottom tensile steel reinforcement. One beam consisted of two $12 \mathrm{~mm}$ diameter bars at the bottom tensile steel reinforcement.

Fig.1. shows the dimensions and details of beams reinforcement.

\subsection{MATERIAL PROPERTIES}

The test specimens used in the program were normal strength concrete using local materials. The materials used in casting the reinforced concrete models were clean sand, graded gravel, water, steel reinforcement, and cement. The specified 28-day cube strength was 31 $\left(\mathrm{fcu}=31 \mathrm{~N} / \mathrm{mm}^{2}\right)$ with a maximum aggregate size of 10 $\mathrm{mm}$. The cement used in all specimens was ordinary Portland cement, while the materials used for repair or strengthening were glass fiber reinforced polymers GFRP and epoxy or carbon fiber reinforced polymers CFRP and epoxy. The properties of these materials were determined from tests carried out according to the standard specifications. The amount of water added was calculated to adjust the water cementing ratio to 0.55 . The yield strength and the ultimate strength of the main reinforcing were $360 \mathrm{~N} / \mathrm{mm}^{2}$. The Glass (GFRP) sheets used in beams had an ultimate strength of 2250 $\mathrm{N} / \mathrm{mm}^{2}$, an elasticity modulus of $70000 \mathrm{~N} / \mathrm{mm}^{2}$, and an ultimate elongation of $2.9 \%$. The Carbon (CFRP) sheets used to strengthen the beams had an ultimate strength of $3500 \mathrm{~N} / \mathrm{mm}^{2}$, an elasticity modulus of $230000 \mathrm{~N} / \mathrm{mm}^{2}$, an ultimate elongation of $1.6 \%$ and had a thickness of $0.13 \mathrm{~mm}$.

\subsection{DESIGN OF TEST PROGRAM}

The variables of the test program and the symbols will be used to describe the conditions of beams were the following:

The percentage of tension reinforcement:

a) Four bars with $12 \mathrm{~mm}$ diameter (A).

b) Three bars with $12 \mathrm{~mm}$ diameter (B).

c) Two bars with $12 \mathrm{~mm}$ diameter (C).

The number of lap spliced bars which varied from:

- Zero (all bars are continuous) (0).

- One (one spliced bar and others are continuous) (1).

- Two (two spliced bars and others are continuous) (2).

- Three (three spliced bars and one is continuous) (3).

- Four (four bars are spliced) (4).

The number of layers of FRP strips:

- One layer (i).

- Three layers (iii).

Fiber type:

- Glass (G)

- Carbon (C).

Reinforcement lap spliced at different location of the same RC beam (D).

Group (1)

Contains four control beams (A0, A1, A2, and A4) the number of lap spliced bars varied from 0 to 4 bars as reference, and reinforced with four bars in tension zone, as shown in Fig.1.a. The difference between the tested beams was the number of lap spliced bars.

Group (2) 
Contains six beams (AGI1, AGI2, AGI4, AGIII1, AGIII2, and AGIII4) with spliced bars varied from 1 to 4 , reinforced with four bars in tension zone and strengthened with one or three layers of glass fiber is showed in Fig.1.b. The difference between the tested beams was the number of layers of FRP strips and the number of lap spliced bars. For one layer of glass fiber reinforced polymers the distance between strips was 50 $\mathrm{mm}$ and the width of the strip is $50 \mathrm{~mm}$. For the three layers of glass fiber reinforced polymers the distance between the strips was $50 \mathrm{~mm}$ and the width of the strip was $50 \mathrm{~mm}$.

Group (3)

Contains three beams (ACIII1, ACIII2, and ACIII4) with lap splices, varying from 1 to 4 bars, reinforced with four bars in tension zone and strengthened with three layer of carbon fiber, the distance between the strips was $50 \mathrm{~mm}$ and the width of the strip was $50 \mathrm{~mm}$ as shows in Fig.1.c. The difference between the tested beams was the number of lap spliced bars.

Group (4)

Contains three beams (AD4, AGID4, and AGIIID4) with lap splices at different places, reinforced with four bars in the tension zone and strengthened with GFRP strips is showed in Fig.1.d. The difference between the tested beams was the number of layers of FRP strips.

Group (5)

Contains two beams (BGIII3 and CGIII2) with lap splices, strengthened with three layers of GFRP strips , the distance between strips was $50 \mathrm{~mm}$ and the width of the strip was $50 \mathrm{~mm}$, spliced $100 \%$ of the reinforce- ment, as shows in Fig.1.e. The difference between the tested beams was the reinforcement ratio.

\subsection{THE TECHNIQUE OF REPAIR AND STRENGTHENING OF REINFORCED CONCRETE BEAMS}

The CFRP sheets, GFRP sheets used in the study were from Sika Company. The epoxy resin used had two components $\mathrm{A}$ and $\mathrm{B}$ that were mixed in $4: 1$ ratio by weight for wrapping the carbon and glass fiber sheets onto the concrete. The samples are air dried prior to the application of FRP wraps. The concrete surface was grinded and cleaned to expose the aggregates for proper application of FRP sheets. A grinder was used for rounding off the sharp corners and removing local unevenness from the surfaces. Once the concrete surface was prepared, epoxy resin was placed on the concrete surface. Then the FRP strips were placed using a steel roller, as shown in Fig. 2.

Five control beams were considered (A0, A1, A2, A4, and AD4), these beams were not strengthened. Beam specimen AD4 had lap splice in different location. The studied parameters are given in Table.1. Four beams were strengthened with one layer of fiber reinforced polymers, the distance between strips was $50 \mathrm{~mm}$ and the width of the strip was $50 \mathrm{~mm}$. nine beams were strengthened by three layers of fiber reinforced polymers the distance between strips was $50 \mathrm{~mm}$ and the width of the strip was $50 \mathrm{~mm}$.

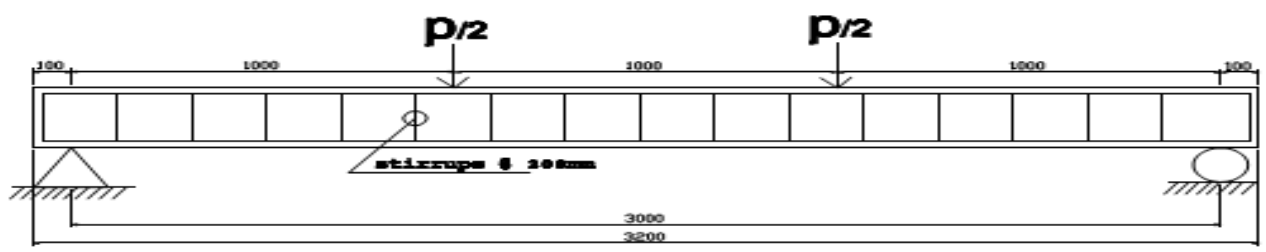

a. (AO)

\section{c. (A2)}

d. (A4)

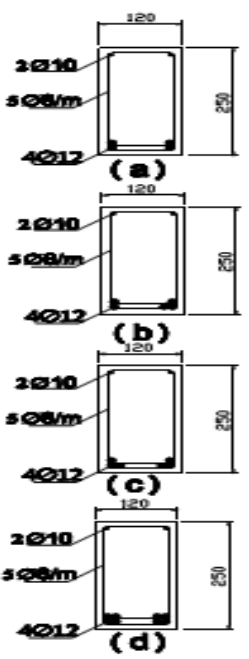

(a) Group. 1 . 


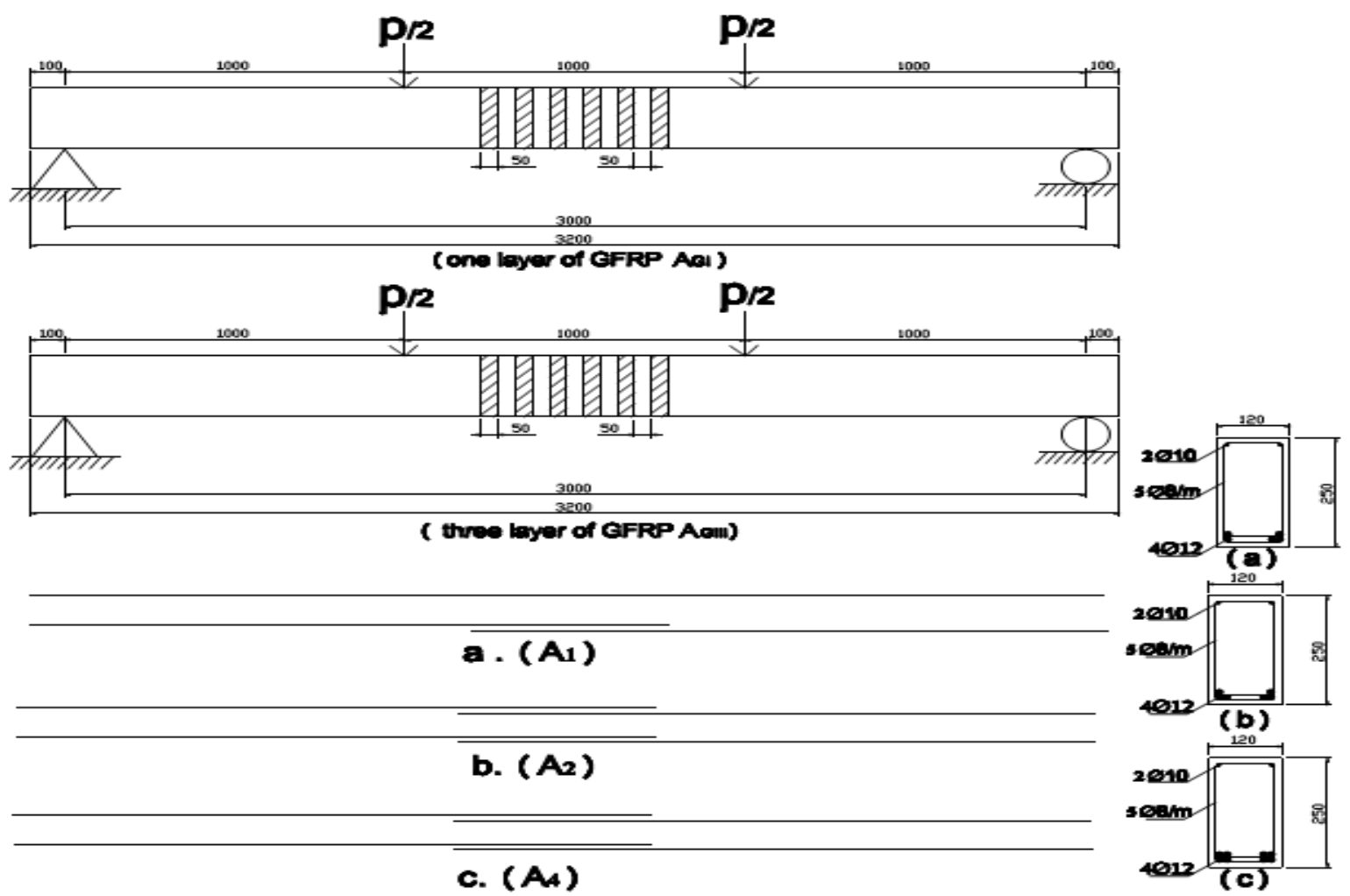

(b) Group 2.

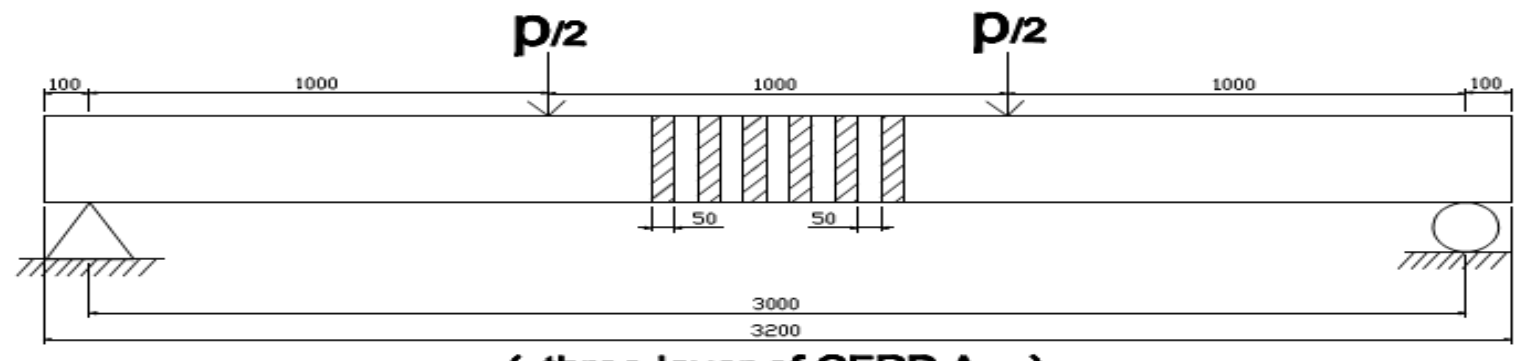

( three layer of CFRP Acil )

(c) Group 3. 

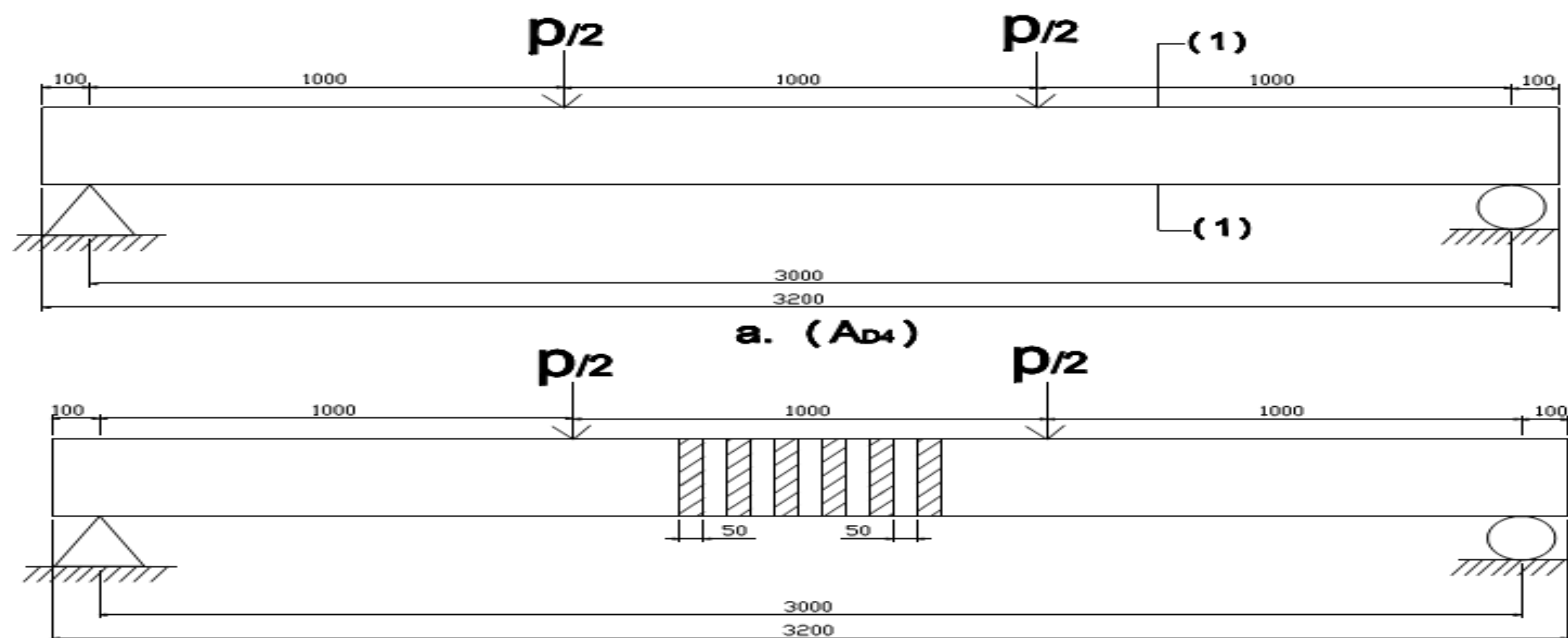

b. (one layer of GFRP Aain4)

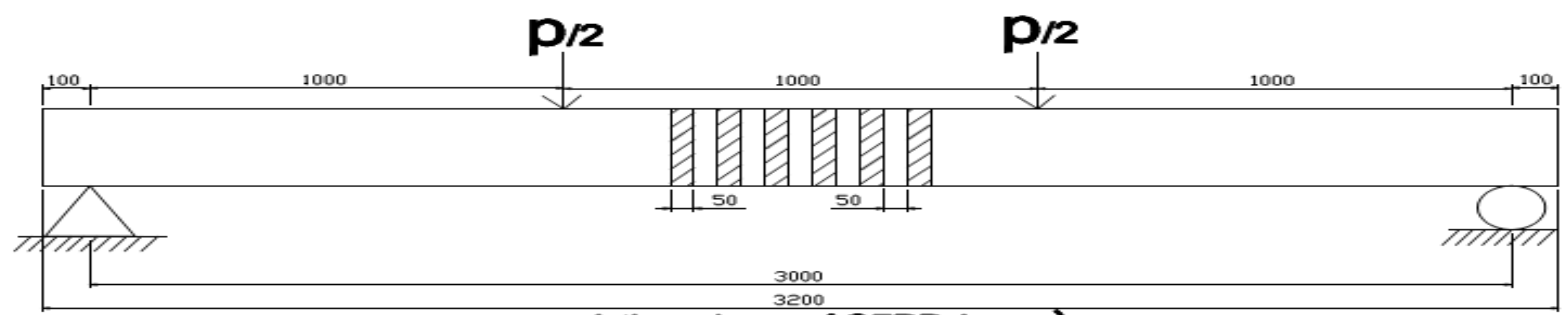

c. ( three layer of GFRP Aamb4)

(d) Group 4.

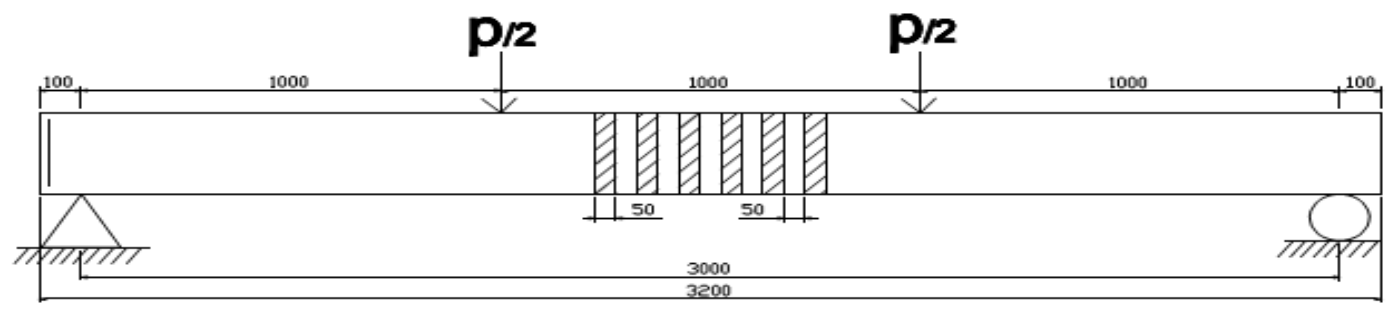

a. (Bour)

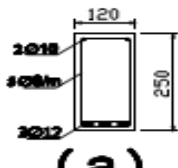

b. (Coilz)

(e) Group 5 .

Fig.1: Dimensions and details of reinforcement of the beams specimens. 


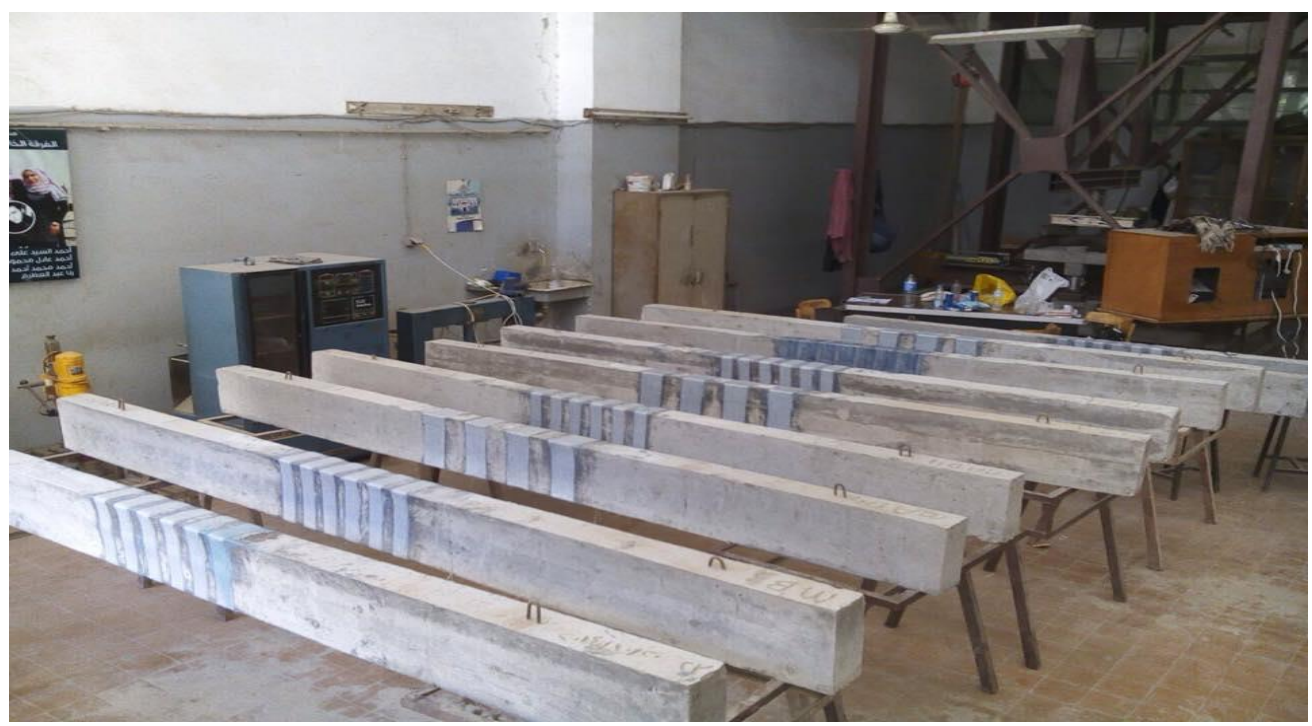

Fig. 2: Beams after strengthening.

Table (1): The experimental test program and strengthening technique.

\begin{tabular}{|c|c|c|c|c|c|c|}
\hline & Group & Beam & $\begin{array}{l}\text { Main rein- } \\
\text { forcement }\end{array}$ & $\begin{array}{l}\text { No. of lap } \\
\text { spliced } \\
\text { bars }\end{array}$ & Lap spliced bars & $\begin{array}{l}\text { Strengthening } \\
\text { technique }\end{array}$ \\
\hline 1 & \multirow{4}{*}{$\begin{array}{l}\overline{0} \\
\text { בे } \\
\text { ō }\end{array}$} & $A_{0}$ & $4 \oiint 12$ & 0 & $\overline{\bar{~}}$ & \\
\hline 2 & & $A_{1}$ & $4 \oiint 12$ & 1 & 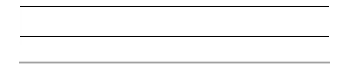 & \\
\hline 3 & & $\mathrm{~A}_{2}$ & $4 \oiint 12$ & 2 & $\bar{\square}$ & \\
\hline 4 & & $\mathrm{~A}_{4}$ & $4 \oiint 12$ & 4 & $\overline{\overline{\overline{ }}}$ & - \\
\hline 5 & \multirow{4}{*}{ 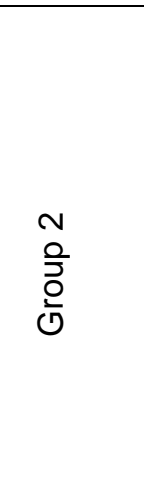 } & $A_{G I 1}$ & $4 \oiint 12$ & 1 & $\overline{\overline{ }}$ & 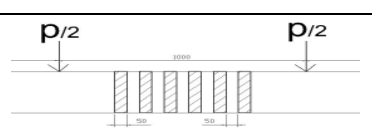 \\
\hline & & & & & & One layer of GFRP strips \\
\hline 6 & & $A_{G \mid 2}$ & $4 \oiint 12$ & 2 & $\overline{\overline{ }}$ & 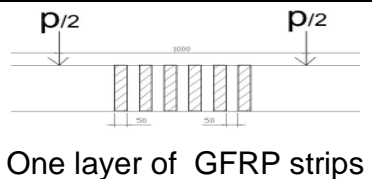 \\
\hline 7 & & $A_{G 14}$ & $4 \oiint 12$ & 4 & $\overline{\overline{\overline{\bar{u}}}}$ & 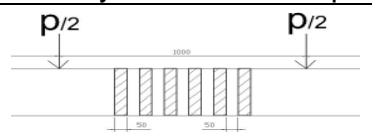 \\
\hline
\end{tabular}


G. I. khaleel, A. S. Debaiky, M. H. Mansour , Marwa I. Badawi " DUCTILITY OF STR...."

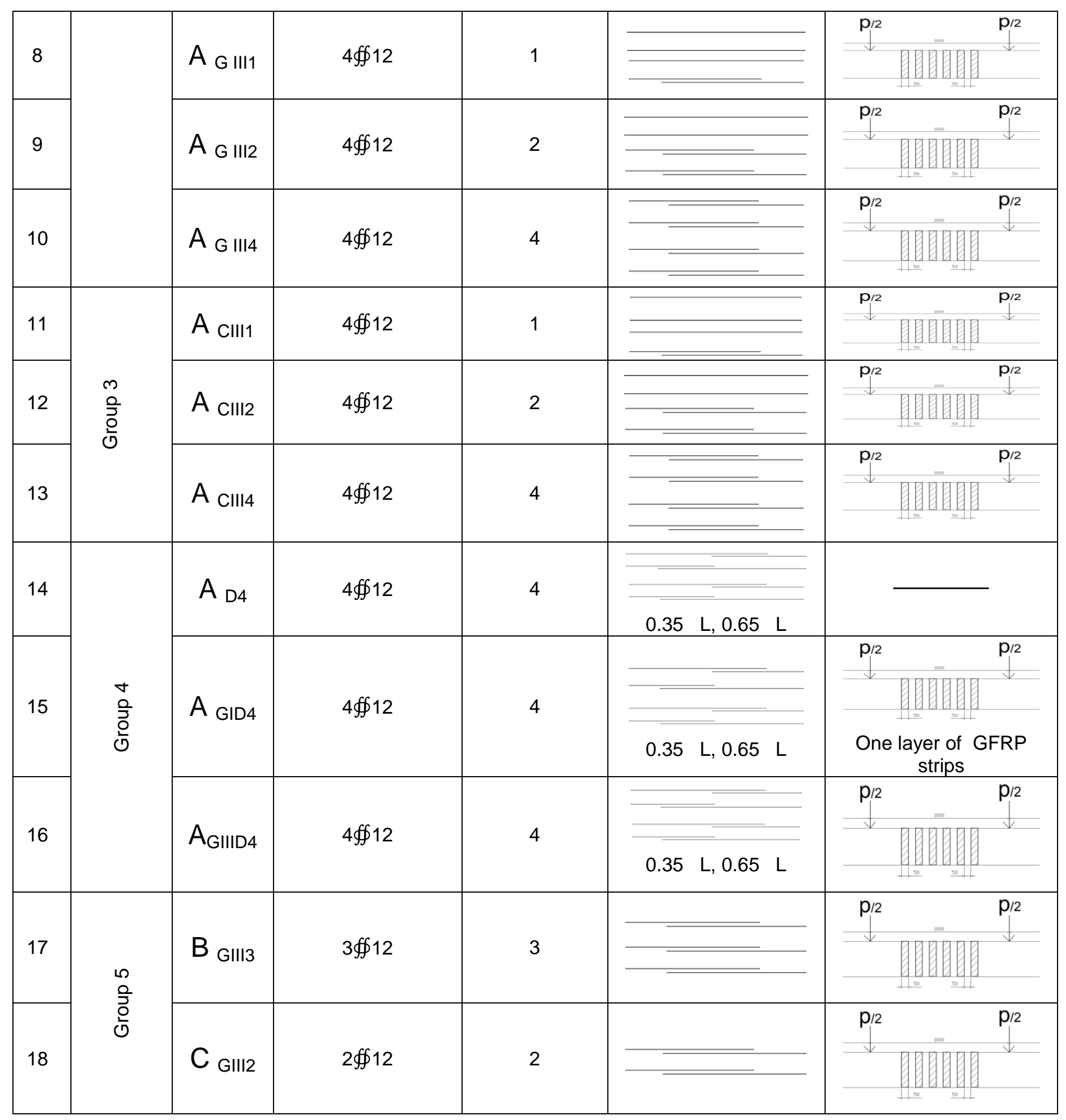

Note: lap splice length $550 \mathrm{~mm}$, bars spliced at $0.5 \mathrm{~L}$ otherwise mentioned.

All beams strengthened by three layers of FRP otherwise mentioned. 


\subsection{TEST SETUP AND TESTING PROCEDURE}

The test set-up used in this research consisted of rigid steel frames supported by the laboratory's rigid floor in the Reinforced Concrete Laboratory at the Faculty of Engineering, Banha University as shown in Fig.3. All the beams were tested under positive bending.

The load was applied through a mechanical screw jack and was transferred to the tested beam through a steel spreader beam which was supported on two steel rollers covering the entire width of the beam to provide 2 concentrated load, as shown in Figs 3,4. The load was measured using electrical load cell under the screw jack, of maximum capacity $1000 \mathrm{KN}$, as shown in Fig.3. The distance between the two applied loads was $1000 \mathrm{~mm}$.

The deflections were measured by three linear variable differential transformers (LVDTs). Two of the LVDTs were placed under the two load points and the third one was under the beam at mid span. The strain on the lap spliced bar was measured. The rotation was measured by two LVDTs. This was done by subtracting the two readings of these LVDTs and dividing the result by the distance between the two LVDTs, as shown in Fig.3.

The load cell and the six LVDTs were connected to a data system for recording.

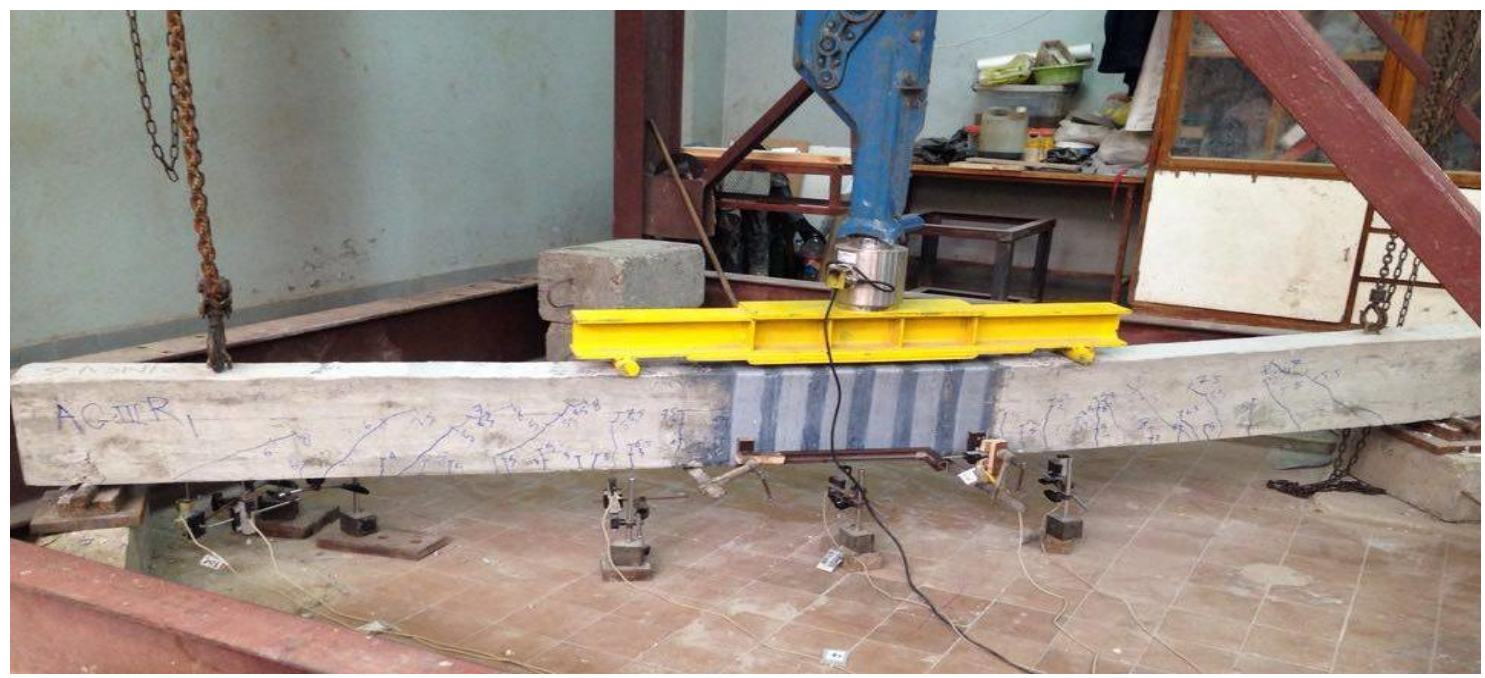

Fig.3: The test set-up.

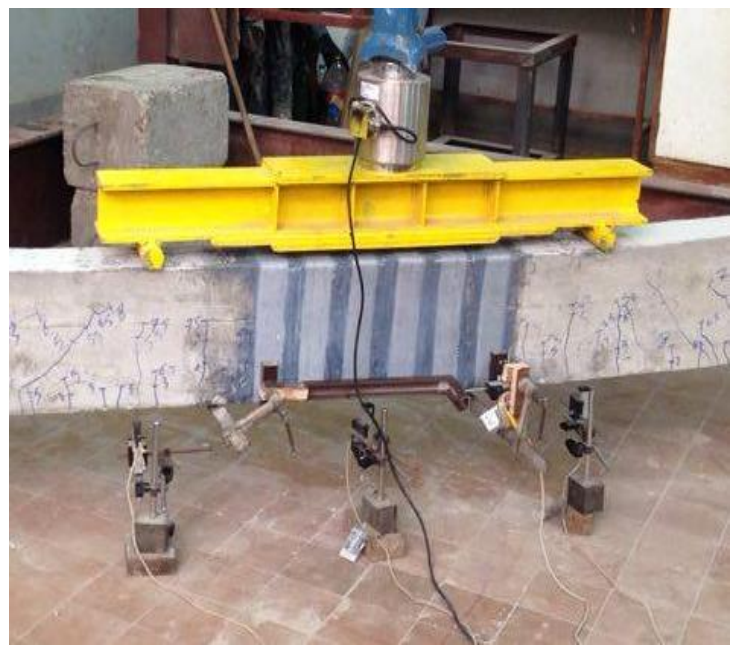

(a) Steel spreader beam and electrical load cell.

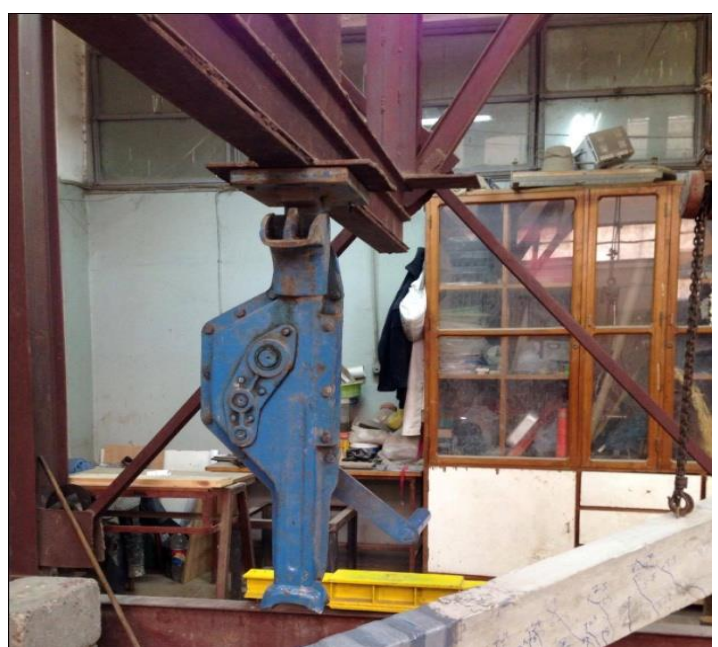

(b) Mechanical screw jack.

Fig.4: Loading system 


\section{EXPERIMENTAL RESULTS AND DISCUSSION}

The experimental results including ultimate loads, corresponding deflection at mid-point, corresponding Final Ductility Factor and failure modes for the beam specimens are summarized in Table 2 . The results obtained from these tests are analyzed in the following.

\subsection{ULTIMATE LOAD}

The ultimate capacity $(\mathrm{Pu})$ of each beam was determined by the peak load attained during loading test. The data collected to determine the increasing of the ultimate capacity of beams due to strengthening beams with CFRP and GFRP.

\subsubsection{THE EFFECT OF NUMBER OF LAP SPLICED BARS}

Fig. 5 shows the relation between the ultimate load and the percentage of spliced bars for the tested beam specimens A0, A1, A2, and A4. The ultimate load of the beam specimens $\mathrm{A} 0, \mathrm{~A} 1, \mathrm{~A} 2$, and $\mathrm{A} 4$ were $81 \mathrm{KN}, 80$ $\mathrm{KN}, 79 \mathrm{KN}$, and $72 \mathrm{KN}$ respectively. This means that the beam specimens A1, A2, and A4 achieved an ultimate load of $98.76 \%, 97.5 \%$, and $88.89 \%$ respectively of that of the control beam specimen A0. It is clear that as the number of lap spliced bars increased the ultimate load decreased.

\subsubsection{COMPARE BETWEEN STRENGTHENING BY ONE LAYER OF GFRP AND THREE LAYERS OF GFRP}

Fig.6 shows the ultimate load for the different strengthened beam specimens with different number of glass fiber reinforced polymer strips in lap splice zone with different number of lap spliced bars.

It is clear that as the number of lap spliced bars increased the ultimate load decreased. The ultimate load of beam specimens AGIII1, AGIII2, and AGIII4 strengthened with three layers of glass fiber strips were higher than that of beam specimens AGI1, AGI2, and AGI4 strengthened with one layer of glass fiber strips by $104.76 \%, 102.44 \%$, and $102.6 \%$ respectively. The ultimate load of beam specimens AGIII1, AGIII2, and AGIII4 strengthened with three layers of glass fiber strips were higher than that of beam specimens A1, A2, and A4 by $110 \%, 106.33 \%$, and $109.7 \%$ respectively. The ultimate load of beam specimens AGI1, AGI2, and AGI4 strengthened with one layer of glass fiber strips were higher than that of beam specimens A1, A2, and A4 by $105 \%, 103.8 \%$, and $106.94 \%$ respectively.

\subsubsection{COMPARE BETWEEN STRENGTHENING BY GFRP AND CFRP}

Fig.7 shows the ultimate loads for the different strengthened beam specimens with different type of fiber reinforced polymer in lap splice zone with different number of lap spliced bars. The ultimate load of beam specimens ACIII1, ACIII2, and ACIII4 were 86 $\mathrm{KN}, 81 \mathrm{KN}, 77 \mathrm{KN}$ respectively. Beam specimens ACIII2, and ACIII4 achieved an ultimate load of 94.2 $\%$ and $89.4 \%$ of that of beam specimen ACIII 1 respectively.

It is clear that as the number of lap spliced bars increased the ultimate load decreased. The ultimate loads of beam specimens AGIII1, AGIII2, and AGIII4 which strengthened with glass fiber were higher than that of beam specimens ACIII1, ACIII2, and ACIII4 strengthened with carbon fiber by $102.4 \%, 103.7 \%$, and $102.6 \%$ respectively. The ultimate load of the beam specimens AGIII1, AGIII2, and AGIII4 strengthened with glass were higher than that of the beam specimens $\mathrm{A} 1, \mathrm{~A} 2$, and A4 by $110 \%, 106.33 \%$, and $109.7 \%$ respectively. The ultimate load of the beam specimens ACIII1, ACIII2, and ACIII4 strengthened with carbon fiber were higher than that of beam specimens A1, A2, and A4 by $107.5 \%, 102.53 \%$, and $106.94 \%$ respectively.

\subsubsection{THE EFFECT OF LAP SPLICE LOCATION}

Fig.8 shows the ultimate load for the different strengthened beam specimens with different number of glass fiber reinforced polymer layers in lap splice zone with lap spliced bars in different places or at the same place. The ultimate load of beam specimens A4D, AGI4D, and AGIII4D were $74 \mathrm{KN}, 80 \mathrm{KN}, 83 \mathrm{KN}$ respectively. Beam specimens AGI4D, and AGIII4D achieved an ultimate load of $111 \%$ and $115.3 \%$ of that of beam specimen A4D respectively.

It is clear that when we changed the place of lap splice the ultimate load increased. The ultimate load of beams specimens A4D, AGI4D, and AGIII4D which we changed the place of lap splice were higher than that of beams specimens A4, AGI4, and AGIII4 which we spliced $100 \%$ of the bars by $102.78 \%, 103.9 \%$, and $105.1 \%$ respectively. The ultimate load of beam specimen AGIII4D strengthened with three layers of glass fiber strips and spliced its bars in different places was higher than that of beam AGI4D strengthened with one layer of glass fiber strips by $103.75 \%$. The ultimate load of beam AGI4D strengthened with one layer of glass fiber strips was higher than that of beam specimens A4D by $108.1 \%$. 


\subsubsection{THE EFFECT OF PERCENTAGE OF TENSION REINFORCEMENT}

Fig.9 shows the ultimate load of beam specimens AGIII4, BGIII3, and CGIII2 with spliced $100 \%$ of reinforcement was $79 \mathrm{KN}, 68 \mathrm{KN}$, and $41 \mathrm{KN}$ respectively. Beam specimens AGIII4 and BGIII3 achieved $187.8 \%$ and $165.85 \%$ of that of beam specimen CGIII2 respectively.

It is clear that as the percentage of tension reinforcement increased the ultimate load increased. For splicing $100 \%$ of the reinforcement, the decreasing of percentage of spliced reinforcement in beam specimens the increasing of ultimate load.

Table 2: Experimental results specimens

\begin{tabular}{|c|c|c|c|c|c|c|c|}
\hline \multicolumn{2}{|c|}{ Tested beam } & $\begin{array}{l}\text { Ultimate } \\
\text { Load Pu } \\
\text { (KN) }\end{array}$ & $\begin{array}{l}\text { Deflection } \\
\text { at mid- } \\
\text { point at } \\
\text { max load. }\end{array}$ & $\begin{array}{c}\text { Deflection } \\
\text { at Py } \\
(\mathrm{mm})\end{array}$ & $\begin{array}{c}\text { Deflection } \\
\text { at } 80 \% \mathrm{Pu} \\
\quad(\mathrm{mm})\end{array}$ & $\begin{array}{c}\text { Final } \\
\text { Ductility } \\
\text { Factor }\end{array}$ & Mode of Failure \\
\hline \multirow[t]{4}{*}{ Group1 } & A0 & 81 & 34.2 & 20 & 47 & 2.350 & Flexure tension \\
\hline & $\mathrm{A} 1$ & 80 & 30.4 & 17 & 38 & 2.235 & Flexure comp- \\
\hline & A2 & 79 & 26.1 & 16 & 35 & 2.188 & Splitting \\
\hline & A4 & 72 & 22.5 & 18 & 30 & 1.667 & Splitting \\
\hline \multirow[t]{6}{*}{ Group2 } & AGI1 & 84 & 38.2 & 17 & 51 & 3.000 & Debonding \\
\hline & AGI2 & 82 & 36.8 & 18 & 49 & 2.722 & Debonding \\
\hline & AGI4 & 77 & 32.5 & 18 & 44 & 2.444 & Debonding \\
\hline & AGIII1 & 88 & 30.4 & 16 & 44 & 2.750 & Flexure tension \\
\hline & AGIII2 & 84 & 29.2 & 18 & 41 & 2.278 & Flexure tension \\
\hline & AGIII4 & 79 & 28.3 & 18 & 40 & 2.222 & Flexure tension \\
\hline \multirow[t]{3}{*}{ Group3 } & ACIII1 & 86 & 36.4 & 17 & 50 & 2.941 & Flexure tension \\
\hline & ACIII2 & 83 & 34.2 & 18 & 46.5 & 2.583 & Flexure tension \\
\hline & ACIII4 & 77 & 30.8 & 18 & 41 & 2.278 & Flexure tension \\
\hline \multirow[t]{3}{*}{ Group4 } & AD4 & 72 & 22.4 & 16 & 27 & 1.688 & Splitting \\
\hline & AGID4 & 80 & 40.3 & 16 & 51 & 3.188 & Debonding \\
\hline & AGIIID4 & 83 & 44.3 & 16 & 54 & 3.375 & Flexure tension \\
\hline \multirow[t]{2}{*}{ Group5 } & BGIII3 & 68 & 26.7 & 16 & 37 & 2.063 & Splitting \\
\hline & CGIII2 & 41 & 24.4 & 14 & 28 & 1.875 & Splitting \\
\hline
\end{tabular}

Py : the yield load; $\Delta$ y: Deflection at yield load.

$\mathrm{Pu} \quad$ : the ultimate load; $\Delta \mathrm{u}$ : Deflection at ultimate load.

$0.8 \mathrm{Pu}: 0.8$ ultimate load; $\Delta 0.8 \mathrm{u}$ : Deflection At 0.8 ultimate loads. 


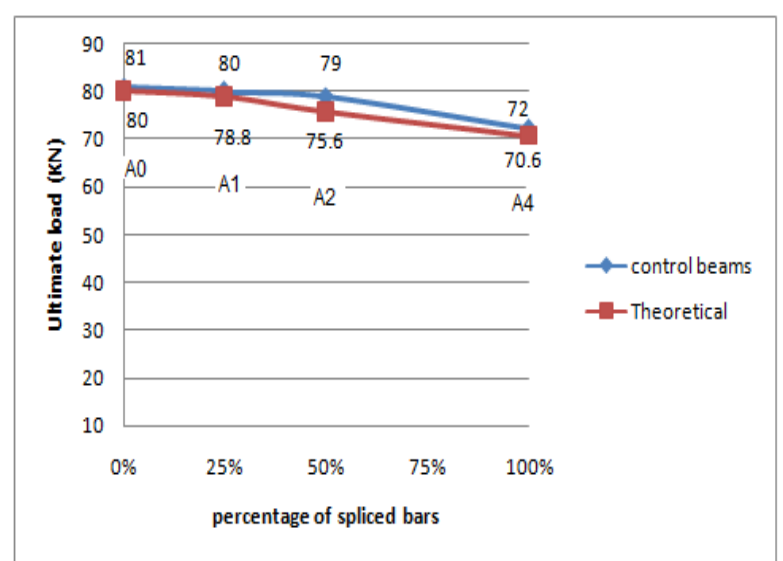

Fig. 5: Ultimate load vs. the percentage of spliced bars.

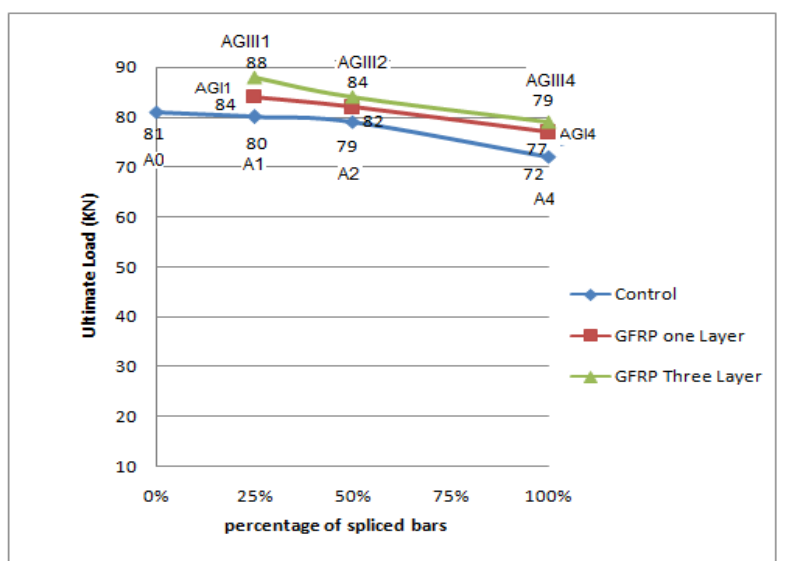

Fig.6: Ultimate load vs. the percentage of spliced bars for different number of GFRP layers.

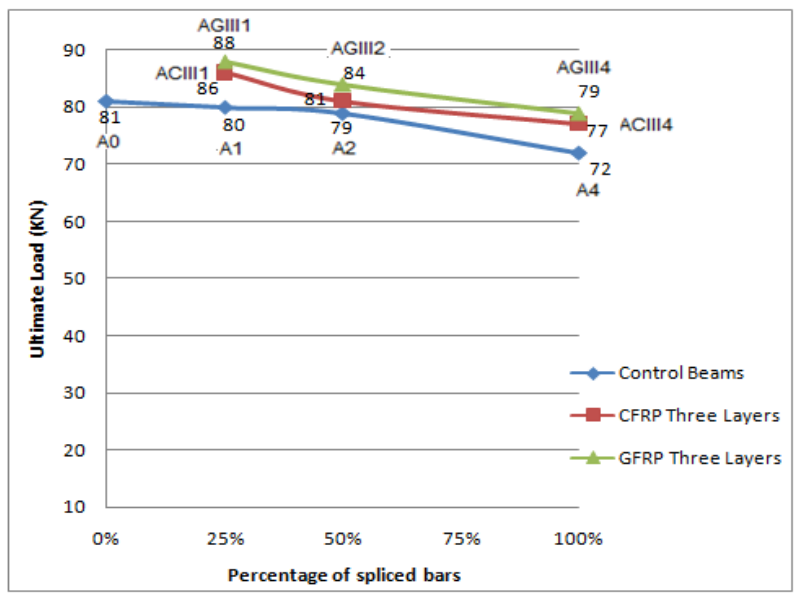

Fig.7: Ultimate load vs. the percentage of spliced bars for different strengthening materials.

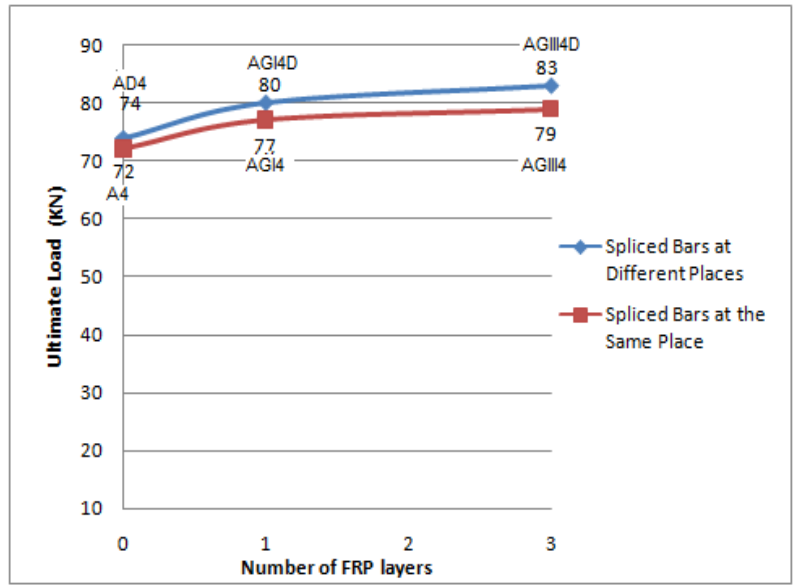

Fig.8: Ultimate load vs. different number of GFRP layers for different lap splice location.

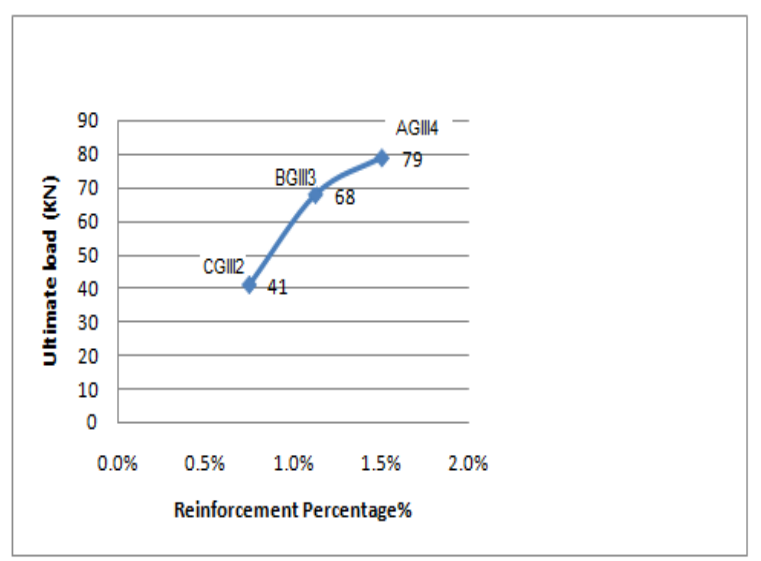

Fig.9: Ultimate load vs. percentage of tension reinforcement for spliced $100 \%$ of reinforcement bars. 


\subsection{DEFLECTION}

Deflection is an important parameter was noticed during the testing of beams. The load-deflection behavior for the beams specimens with different percentage of lap spliced bars, one layer of GFRP, three layers of GFRP strips, three layers of CFRP strips, different lap splice location and different percentage of tension reinforcement are shown in Fig.10 to Fig.16.

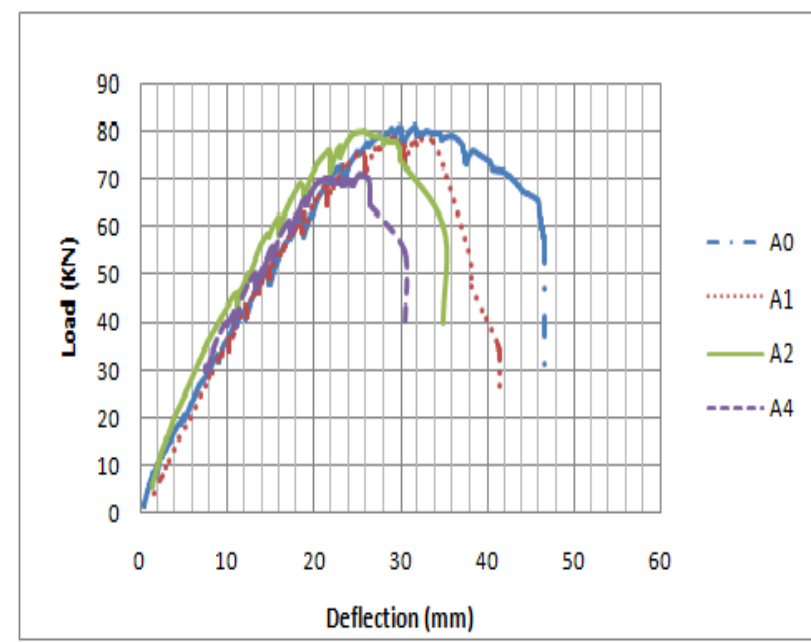

Fig. 10: Load-Deflection curves for control specimens.

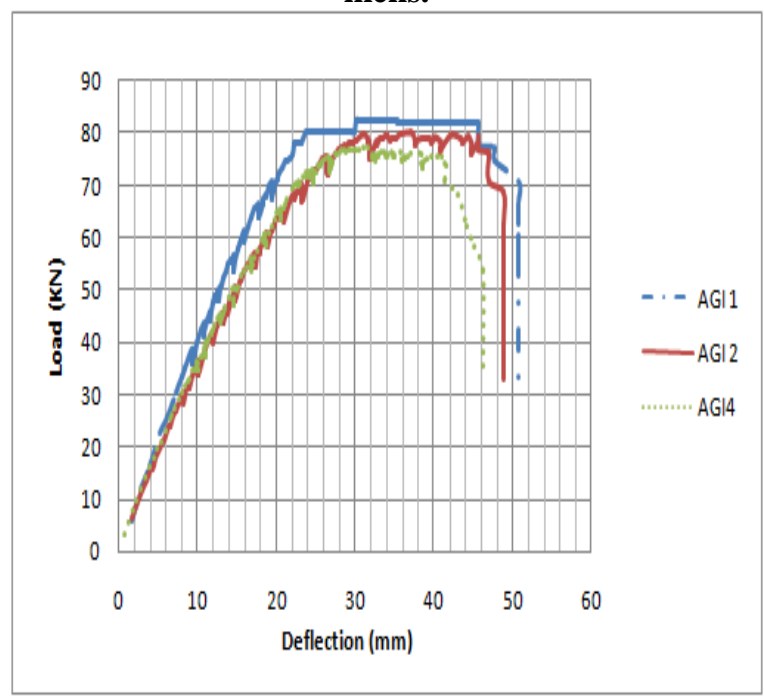

Fig. 11: Load-Deflection curves for specimens with GFRP (one layer).

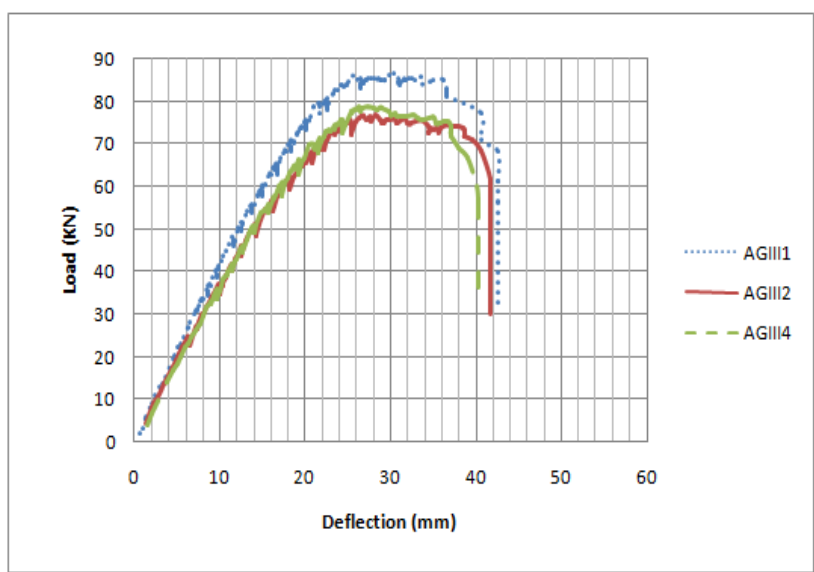

Fig. 12: Load-Deflection curves for specimens with GFRP (three layers).

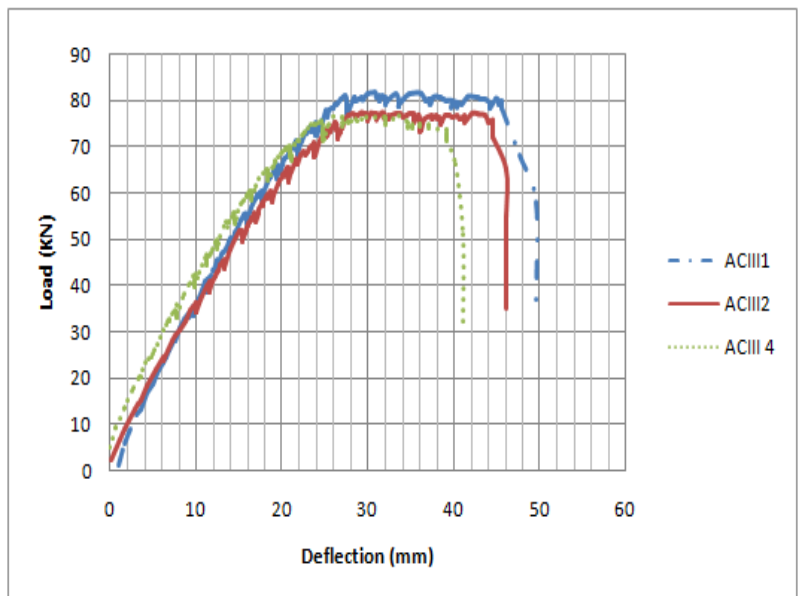

Fig. 13: Load-Deflection curves for specimens with CFRP (three layers).

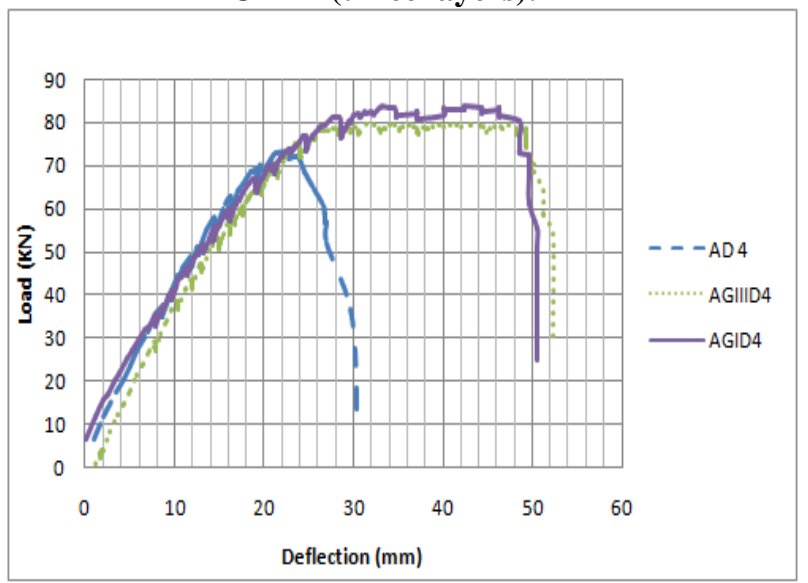

Fig. 14: Load-Deflection curves for specimens with different number of GFRP layers for different lap splice location. 


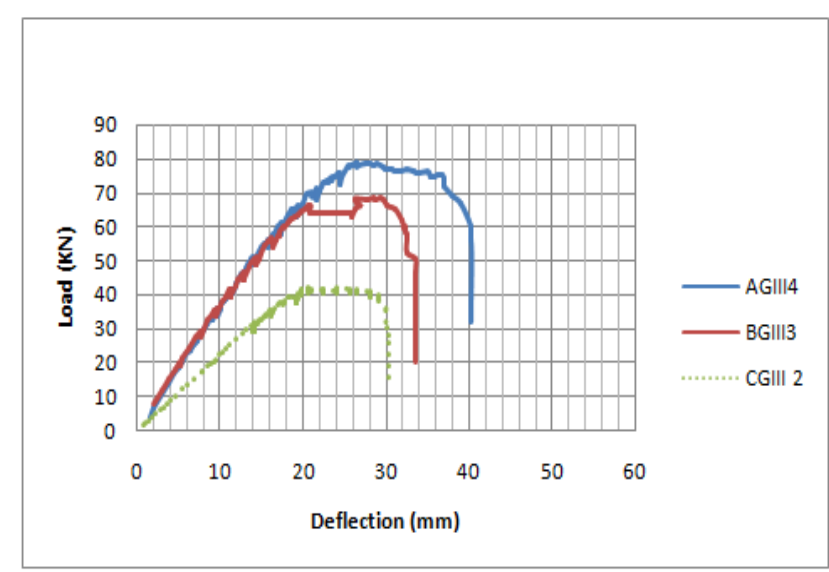

Fig. 15: Load-Deflection curves for specimens with different percentage of tension reinforcement for spliced $100 \%$ of reinforcement bars.

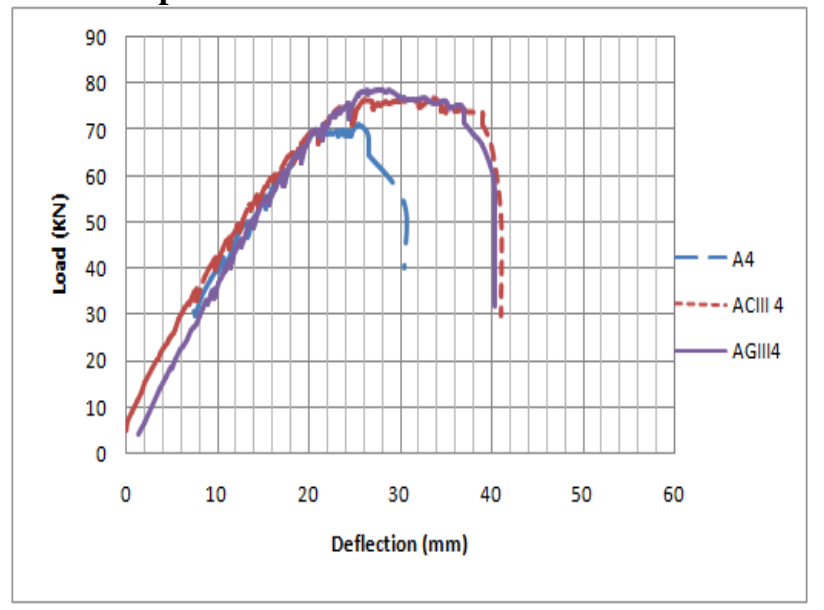

Fig. 16: Load-Deflection curves for specimens for different strengthening materials.

\subsection{DUCTILITY RATIO}

Ductility is one of the most important parameters to reflect the plastic deformability of members and structures. Ductility factor defined as the ratio between the maximum deflection (the mid span deflection when the load decreased to $80 \%$ of the ultimate value along the descending branch of the load deflection curve) and the yielding deflection (the mid span deflection at tension steel yielding), as shown in Table 2.

The final ductility factor for the beams specimens with different percentage of lap spliced bars, one layer of GFRP, three layers of GFRP strips, three layers of CFRP strips, different lap splice location and different percentage of tension reinforcement are shown in Fig.17 to Fig.21.
As shown in the curves of loads versus mid span deflection, FRP wrapping strengthened beams significantly improved both ultimate load, deflections prior to failure of beam which were greater than of the control beam, the use of FRP sheets produced higher deflection for the same load up till failure than control, for all stages of loading up to failure.

As indicated by comparison of the beam specimens, spliced the bars at different place and different number of glass fiber layers at lap spliced zone, the deformation before failure increased as the place of lap splice changed, and with increasing the number glass fiber layers.

As indicated by comparison of beam specimens with different percentage of tension reinforcement, the deformation before failure increased as the ultimate load increased, and this increase was more rapid with increasing the percentage of tension reinforcement, and also accompanied by increasing in load.
It is clear that as the number of GFRP layers increased the final ductility factor increased. The final ductility factor of beam specimens AGI1, AGI2, and AGI4 strengthened with one layer of glass fiber strips were lower than that of beams AGIII1, AGIII2, and AGIII4 strengthened with three layers of glass fiber strips by $9.1 \%, 13.9 \%$, and $10 \%$, respectively.

As indicated by comparison of test results of beam specimens with different number of glass fiber reinforced polymer layers in lap splice zone. The final ductility factor increased as the number of glass fiber reinforced polymer layers in lap splice zone increased and this increase was more rabid with the decreasing of the number of lap spliced bars.

It is clear that as GFRP layers used in strengthening the beams, the final ductility factor increased. The final ductility factor of beam specimens AGIII1, AGIII2, 
and AGIII4 strengthened with glass fiber were higher than that of beam specimens ACIII1, ACIII2, and ACIII4 strengthened with carbon fiber by $2.01 \%, 5.4 \%$, and $7.29 \%$, respectively.

It is clear that as we changed the place of lap splice the final ductility factor increased.

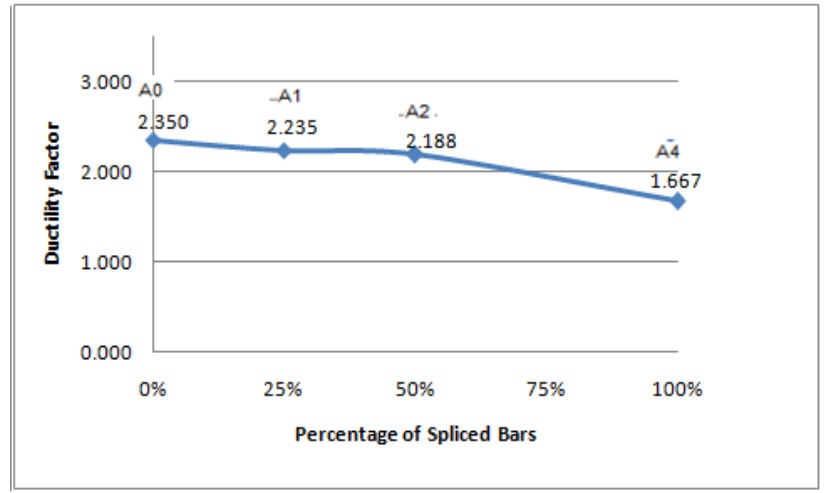

Fig.17: the ductility factor for control specimens.

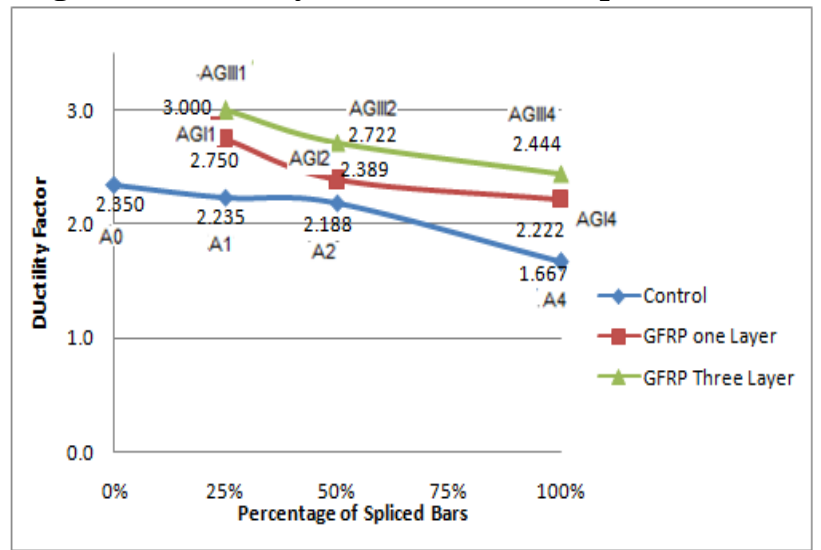

Fig.18: Ductility factor vs. the percentage of spliced bars for different number of GFRP layers
It is clear that as the percentage of tension reinforcement increased the final ductility factor increased. For $100 \%$ of the reinforcement spliced, the increasing of the percentage of spliced reinforcement in the beam specimens decreased the final ductility factor.

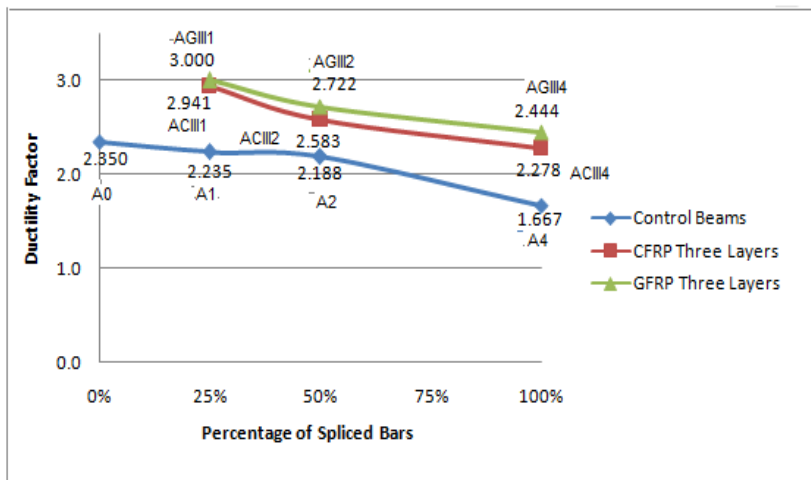

Fig.19: Ductility factor vs. the percentage of spliced bars for different strengthening materials.

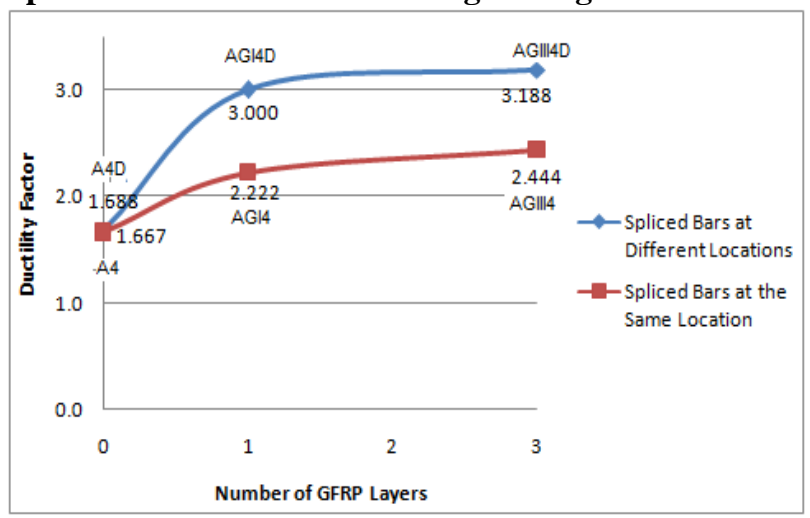

Fig.20: Ductility factor vs. different number of GFRP layers for different lap splice location.

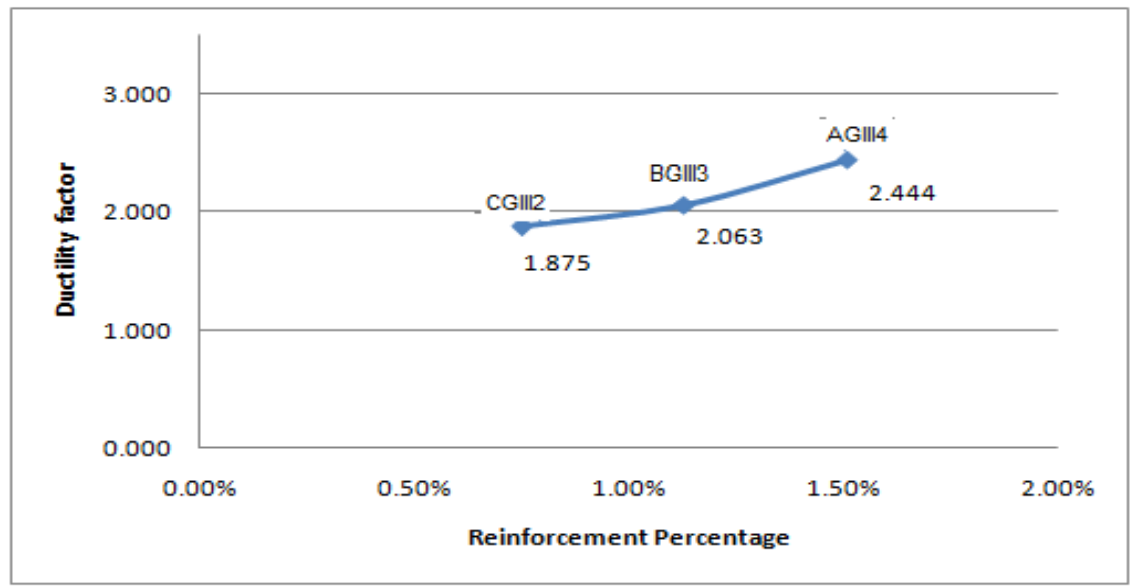

Fig.21: Ductility factor vs. percentage of tension reinforcement for spliced $100 \%$ of reinforcement bars. 


\subsection{THE FAILURE MODE}

In all specimens, the first crack, cracks propagation, and plane of failure were observed to investigate the cracking behavior and mode. The modes of failure of all beam specimens are given in Table (2).

$\mathrm{UN}$ wrapped, $\mathrm{A}_{0}, \mathrm{~A}_{1}$ beams specimens failed in flexure with diagonal tension cracks increasing in ultimate load to fracture in the middle span between two points of loading as shown in Fig.21. Specimens $A_{2}$, $\mathrm{A}_{4}, \mathrm{~A}_{\mathrm{D} 4}$ failed by Splitting failure a horizontal splitting crack along the splice length appeared, with a small load increase, a sudden bond failure occurred and the bottom cover at the splice zone separated from the beam as shown in Fig.22.

All beams with one layer of fiber wrapped, failed by debonding of fiber and concrete failure in middle span between two points of loading. A ductile failure took place accompanied by the debonding of some fiber strips, as shown in Fig.23.

Three layer of fiber wrapped, all beams failed by flexure failure in middle span between two points of loading. As the applied load increased, the developed cracks propagated rapidly from the tension side towards the compression side, as shown in Fig.24.

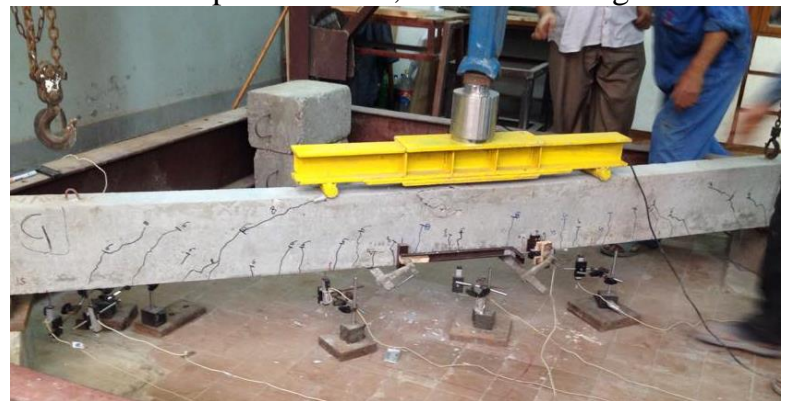

Fig.21: shows failure mode of un-wrapped (A1).

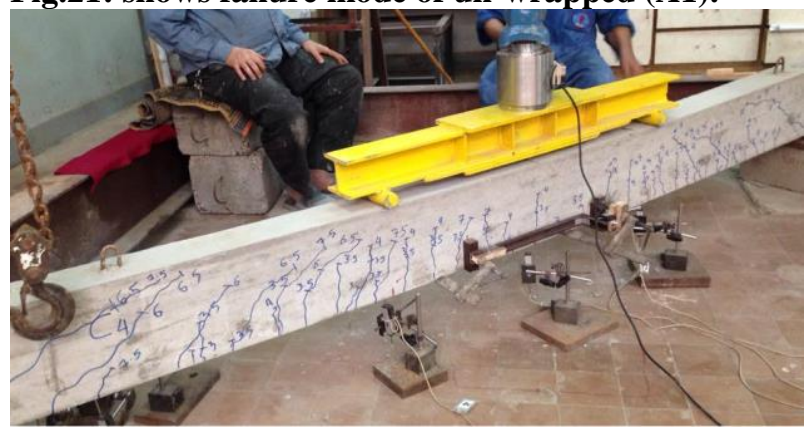

Fig.22 shows failure mode of splitting failure (A4).

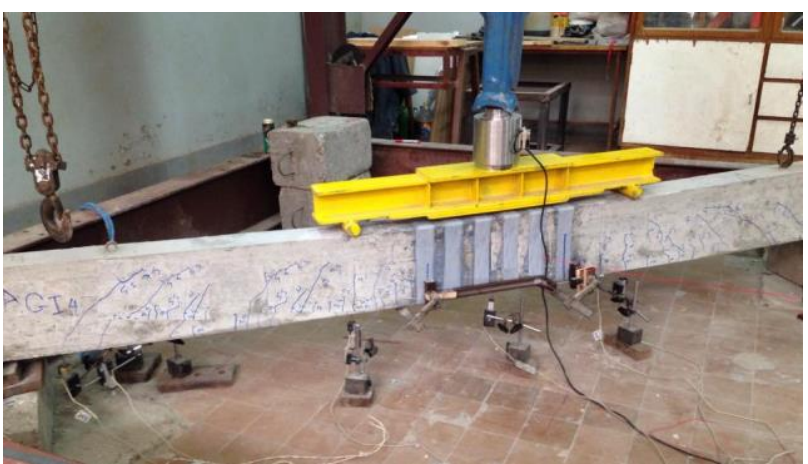

Fig.23 shows debonding in fiber (AGI4).

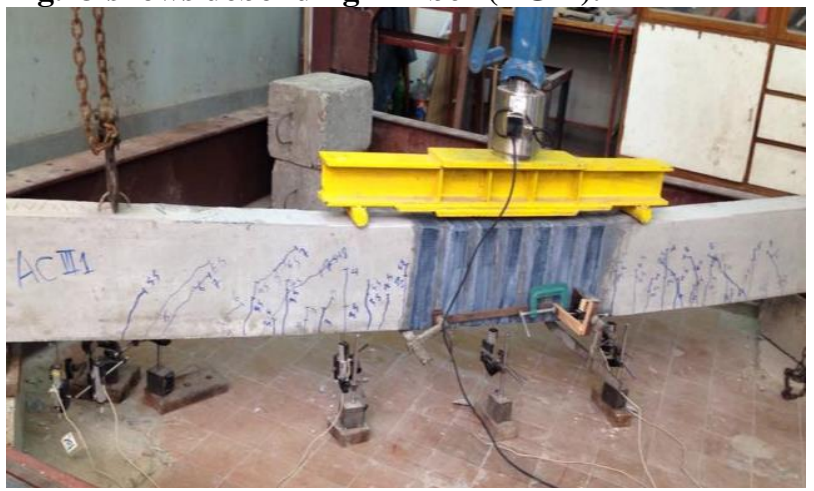

Fig.24 shows the failure mode flexure (ACIII1). 


\section{CONCLUSIONS}

Based on the investigation and experimental results described, a number of conclusions may be considered for FRP wrapping to confining the splice region on the tension lap splice length. The factors to be taken into account are ultimate load, deflections, ductility factor. Conclusions obtained in this study were as follows.

1. In general, FRP strips wrapping provided greater ease of application, make beams more ductility, additional flexural reinforcement that refers to FRP act as confinement material as well.

2. The deflection of the strengthened beam was less for each load case compared to the unstrengthened beam, the strengthened beams suffered higher deflection compared to the reference beam.

3. The strengthening with FRP showed more deflection during concrete failure so more warning and saving of lives before failure.

4. The curves indicate that the deflection of the GFRP strengthened beam was more for each load case compared to the CFRP strengthened beam, CFRP was better than GFRP in deflection.

5. The mode of failure for beams with FRP wraps was ductile and the failure was gradual after the load reached the peak. The final failure of the beams strengthening with one layer of GFRP was debonding of GFRP layers from the sides and bottom of the beam with longitudinal splitting in the concrete cover, and flexure failure for the beams strengthening with three layer of GFRP or CFRP.

6. The yielding and ultimate loads of the tested beams seem to have a light effect by using lap splices of reinforcing bars in the constant moment zone, with a length equal to that recommended by the Egyptian code.

7. As the percentage of spliced bars increased over $25 \%$ of the total bars, the ductility of the beams decreased.

8. For beams with spliced bars the major crack concentrated at the start and end of the spliced zone.
9. Future work can investigated different techniques of fiber reinforced polymers.

\section{REFERENCES}

1. Shaker A. El-Behairy, Hamdey H. Shaheen, Gamal I. Khaleel, Ahmed I. Abdel Mouti], "Curvature Ductility of Reinforced Concrete Beams", Thesis, Ain Shams University, Cairo, Egypt, 1994.

2. Oguz Gunes, Denvid Lau, Chakrapan Tuakta, Oral Büyüköztürk, "Ductility of FRPConcrete Systems: Investigations at Different Length Scales", Construction and Building Materials 49, 2013, 915-925pp.

3. Mourad M. Bakhoum, and Amr A. Abdelrahman, "Innovative Application of CFRP Strips for Repair of Concrete Beams", Hurghada, Egypt, April, 450-457pp.

4. Gamal Ismail khaleel, "Strengthening and Repair of Reinforced Concrete Beams in Flexure Using GFRP Sheets", 2002, pp.

5. ACI Committee 318, "Building Code Requirements for Structural Concrete (ACI 318-02)", American Concrete Institute, FarmingKN Hills, MI, 2002, 443pp.

6. ACI Committee 318, 2005, "Building Code Requirements for Structural Concrete (ACI 318-05) and Commentary (318R-05)", American Concrete Institute, FarmingKN Hills, Mich, 430pp.

7. Magda I. Mousa, "Flexural Behaviour and Ductility of High Strength Concrete (HSC) Beams with Tension Lap Splice ", Alexandria Engineering Journal, Volume 54, Issue 3, September 2015.

8. Alfredo Roberto Donoso Di Donato," Flexural Ductility of Reinforced Concrete Beams", Thesis, Faculty of Engineering, University of the Witwatersrand, Johannesburg, JULY, 1984. 